Table 1. OXYTOCIC ACTIVITY OF EXTRACTS OF BLOOD AND HYPoTHaLAMUS IN RATS

\begin{tabular}{|c|c|c|c|c|c|c|c|}
\hline \multicolumn{4}{|c|}{ Blood } & \multicolumn{4}{|c|}{ Hypothalamus } \\
\hline $\begin{array}{c}\text { Total } \\
\text { oxytocic } \\
\text { activity }\end{array}$ & $\begin{array}{l}\text { Oxytocin } \\
\text { u. } / \mathrm{ml} \text {, blo }\end{array}$ & $\begin{array}{c}\text { Second } \\
\text { oxytocic } \\
\text { substance }\end{array}$ & $\begin{array}{l}\text { Second oxytocic } \\
\text { substance/total } \\
\text { oxytocic activity } \\
\text { (per cent) }\end{array}$ & $\begin{array}{l}\text { Total } \\
\text { oxytocic } \\
\text { activity }\end{array}$ & $\begin{array}{l}\text { Oxytocin } \\
\text { hypothala }\end{array}$ & $\begin{array}{c}\text { Second } \\
\text { oxytocic } \\
\text { stubstance }\end{array}$ & $\begin{array}{c}\text { Second oxytocic } \\
\text { substance/total } \\
\text { oxytocic activity } \\
\text { (per cent) }\end{array}$ \\
\hline $\begin{array}{l}1 \cdot 8 \\
1 \cdot 75 \\
2 \cdot 38\end{array}$ & $\begin{array}{l}0 \cdot 34 \\
1 \cdot 00 \\
0 \cdot 65\end{array}$ & $\begin{array}{l}1 \cdot 46 \\
0 \cdot 75 \\
1 \cdot 73\end{array}$ & $\begin{array}{l}81 \\
43 \\
72\end{array}$ & $\begin{array}{r}8 \cdot 28 \\
7 \cdot 66 \\
10 \cdot 42\end{array}$ & $\begin{array}{l}0 \\
5 \cdot 38 \\
3 \cdot 26\end{array}$ & $\begin{array}{c}10 \cdot 1 \\
2 \cdot 28 \\
7 \cdot 16\end{array}$ & $\begin{array}{r}>100 \\
30 \\
70\end{array}$ \\
\hline
\end{tabular}

blood and hypothalamus of the male rat are shown in Table 1. In each case, extracts of hypothalami and blood were made from the same rat and assayed in parallel on the sensitized virgin rat uterus.

Secondly, blood extracts prepared from male rats with bilateral electrolytic lesions in the region of the paraventricular nuclei (using the Horsley-Clark stereotaxic instrument) possessed less oxytocic activity than similar extracts both from the control group and from those with lesions in the posterior hypothalamus. Table 2 shows that most of the oxytocic activity in these male rat blood extracts is due to second oxytocic substance, and since in the last group the total oxytocic enctivity in each case is less than the amount of second oxytocic substance in the first two groups, it suggests a decresse in the level of that substance in the blood as a consequence of the lesions in the paraventricular nuclear area.

Table 2. OXYTOCIC ACTIVITY OF BLOOD EXTRACTS AETER LEgTOXS IN HYPOTHALAMUS

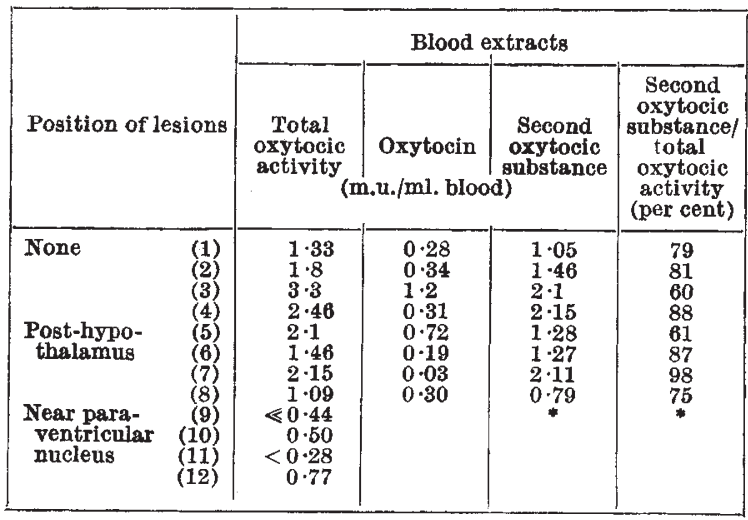

- Insufficient extract left for assay of second oxytocic substance.

Thus it appears that the second oxytocic substance is closely related to oxytocin in its relesse from the paraventricular nucleus. This would explain its reduction following paraventricular lesions, and also the correlation between the level of second oxytocic substance in blood and hypothalamic extracts. Further experiments are being carried out along these lines to confirm these preliminary results.

Department of Physiology,

$$
\begin{aligned}
& \text { A. W. Duggan } \\
& \text { G. W. RED }
\end{aligned}
$$

University of Queensland, Brisbane, Australia. Feb. 17.

${ }^{1}$ Olivecrons, H., Acta Physiol. Scand., 40 (136), 144 (1957).

2 Robertson, P. A., and Hawker, R. W., Nature, 180, 343 (1957)

${ }^{3}$ Van Dyke, H. B.. Chow, B. F., Greep, R. O., and Rothen, A., J. Pharmacol. Exp. Therap., 74, 190 (1942).

- Hawker, R. W., and Robertson, P. A., J. Clin. Endocrinot. Metab. 17, 448 (1957); Endocrinol., 60, 652 (1957).

${ }^{5}$ Hawker, R. W., and Roberts, V. S., Brit. Vet. J., 113, 459 (1957).

\section{Absence of Abnormal Hzmoglobins in Some Groups of the Papua Population of Dutch New Guinea}

As results of various surveys on the occurrence of hæmoglobinopathies in different countries become available it appears that the number of carriers of one of these hereditary aberrations is relatively high among the populations of many countries : Central and North Africa, Italy, Greece, the Middle Eastern countries, Iran, India, Pakistan, Ceylon, Burma, Thailand and Indonesia. In many of these countries malaria is common. There are positive indications that the presence of hrmoglobins $S$ and $F$ lowers the mortality-rate of young children infected with malaria. For the other abnormal hæmoglobins such a relation has not yet been esteblished. Lie Injo Luan Eng' found among the Sudanese and Javanese populations of Jave respectively that 2.5 and 4.5 per cent were carriers of hæmoglobin $\boldsymbol{E}$. Lehmenn et al. ${ }^{2}$ found 13.1 and 5 per cent respectively in the Malaysian Malays of two districts. In the Dyaks of Sarawak the number of hæmoglobin $E$ carriers was found to be very low $^{3}$. Farther east, in the Celebes, the percentage of carriers of hæmoglobin $E$ was found to be low (1 per cent). Lie Injo Luan Eng ${ }^{1}$ and Lehmann et al.4 found no abnormal hæmoglobin in the Australian aborigines.

We have been able recently to study the blood of East Indonesians from Ambon and other islands in the eastern part of the archipelago who have come to Holland (135 samples) together with the blood of Papuans collected by one of us in Dutch New Guinea (250 samples). Both paper electrophoresis and column chromatography were carried out on each specimen. No abnormal hæmoglobin was encountered, nor any increased amount of fœtal hæmoglobin. It is noteworthy that in many parts of Now Guinea malaria is holo-endemic. In the holo-endemic malaria districts of Central Africa, the spleen index among the adult population is far lower than that found in New Guinea. The question arises whether there is a relation between the high spleen index in the adult Papuan and the absence of abnormal hæmoglobins in this population.

\section{J. H. P. JonxIS}

T. H. J. HUISMAN

Department of Pædiatrics,

University of Groningen, The Netherlands.

Camp Westenbork,

$$
\text { G. J. DA CostA }
$$
The Netherlands.

Governmental Medical Service,

\section{Metsertaar}

Hollandia, Binnen,

Dutch New Guinea. Feb. 8.

1 Lie Injo Luan Fng, thesis, Jakarta (1956).

' Lehmann, H., and Rhagwan Singh, R., Nature, 178, 695 (1956).

- Colbourne, M. J., Ikin, E. W., Mourant, A. E., Lehmann, H., and Thein, H., Nature, 181, 119 (1958).

4 Horsfall, W. R.. and Lehmann, H., Nature, 177, 41 (1956). 